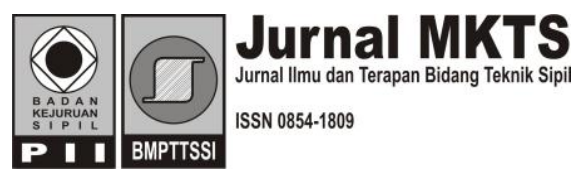

\title{
Perilaku Nonlinier Buckling pada Struktur Cangkang Bola
}

\author{
Sumirin \\ Jurusan Teknik Sipil, Fakultas Teknik, Universitas Islam Sultan Agung \\ J1. Raya Kaligawe Km. 04 Semarang \\ E-mail: sumirinms@gmail.com \\ Nuroji \\ Jurusan Teknik Sipil, Fakultas Teknik, Universitas Diponegoro \\ J1.Prof. Soedarto, SH, Tembalang, Semarang 50275 \\ E-mail: nrji@sipil.ft.undip.ac.id; ojiksam2000@yahoo.com
}

\begin{abstract}
This paper presents the results of a numerical study using the finite element method in geometrical nonlinear on camped shallow spherical shells under uniform pressure. The shell structure was modelled by finite axisymmetric thin shell elements and quadrilateral elements. The geometrical nonlininear problem was solved by a scheme of incremental iterative procedures applying Newton-Raphson method in combination with arch length methods. The results of finite element analysis compared with the experimental results of previous reseacher.
\end{abstract}

Keywords: Information, Rasionalization, Kagan, Stepwise, Weight factor, Hydrological network

\begin{abstract}
Abstrak
Tulisan ini menyajikan hasil studi numerik dengan menggunakan metode elemen hingga nonlinier geometri pada struktur cangkang bola bertumpuan jepit dengan beban tekanan merata. Struktur shell dimodelkan elemen cangkang tipis simetri sumbu dan elemen cangkang segiempat. Masalah nonliniar geometri diselesaikan dengan metode incremental-iteratif metode Newton-Raphson dan kombinasi dengan teknik panjang busur. Hasil analisis elemen hingga dibandingkan dengan hasil eksperimen peneliti terdahulu.
\end{abstract}

Kata-kata Kunci: Informasi, Rasionalisasi, Kagan, Stepwise, Weight factor, Jaringan hidrologi.

\section{Pendahuluan}

Buckling didefinisikan sebagai keadaan batas ultimate di mana struktur tiba-tiba kehilangan stabilitas di bawah gaya membran tekan dan atau geser, yang menyebabkan baik perpindahan besar atau struktur tidak mampu memikul beban (Eurocode 3, 2007). Buckling merupakan fenomena instabilitas yang terjadi pada batang langsing, pelat dan cangkang yang tipis. Konsekuensi buckling pada dasarnya adalah masalah geometri, dimana terjadinya perpindahan besar akan mengubah geometri struktur yang membawa konsekuensi dalam metode analisis struktur.

Fenomena buckling pada struktur kolom langsing merupakan prototipe sederhana yang menggambarkan masalah instabilitas struktur. Masalah instabilitas buckling batang kolom pertama kali dalam sejarah dapat dipecahkan oleh Euler pada tahun 1744 M (Timoshenko dan Gere, 1961). Karakteristik mendasar dari keruntuhan buckling adalah beban runtuh tergantung pada modulus elastisitas dan kekakuan penampang dan hampir tidak tergantung kepada kekuatan bahan atau batas kelelehan bahan.

Secara umum ada dua jenis instabilitas buckling ditinjau dari metoda analisis yaitu linear buckling dan nonlinear buckling (Lagace, 2002). Metode pertama, yaitu analisis pada linear buckling disebut sebagai linear bifurcation eigenvalue buckling, beban kritis buckling dianalisis pada titik bifurkasi dari idealisasi struktur elastis linier dengan menyelesaikan masalah nilai eigen. Analisis pendekatan dengan nilai eigen ini hasilnya konservatif, tetapi karena relatif lebih mudah dan cepat umumnya dapat digunakan sebagai pendekatan awal. Metode kedua, yaitu analisis 
pada nonlinear buckling yang hanya dapat diselesaikan dengan analisis nonlinier geometri.

Perilaku buckling nonlinier pada struktur cangkang pertama kali ditunjukkan oleh Von Karman dan Tsien pada tahun 1939 (Karman dan Kerr, 1962). Penelitian pada cangkang bola dangkal selanjutnya dilakukan antara lain oleh Budiansky, Kaplan dan Fung (Kaplan, 1954). Bertahun-tahun orang berusaha untuk memecahkan persamaan diferensial masalah nonlinear pada cangkang akan tetapi kemajuannya masih lambat (K.Y., Yeh, et.al, 1980). Masalah buckling nonlinier pada cangkang dapat dipecahkan dengan metode elemen hingga nonlinier geometri dilakukan oleh Nygard pada tahun 1986 untuk kasus cangkang silindris akibat beban terpusat (Felippa, 2004). Uchiyama dan Yamada (2000) melakukan studi model cangkang bola jenis elemen hingga nine-node-shell untuk melihat pengaruh ketidaksempurnaan (imperfection) geometri.

Dalam penelitian ini akan dikaji perilaku buckling pada struktur cangkang bola bertumpuan jepit dengan beban tekanan merata. Metode elemen hingga nonlinier geometri digunakan dalam penelitian ini dengan menggunakan Program ANSYS.

Penelitian ini bertujuan untuk mengetahui perilaku buckling nonlinier cangkang bola dengan membandingkan hasil antara analisis elemen hingga dengan hasil eksperimen dari peneliti terdahulu.

\section{Metodologi}

\section{Deskripsi masalah}

Penelitian ini dilakukan terhadap model struktur cangkang bola bertumpuan jepit seperti ditunjukkan pada Gambar 1. Model yang diuji dalam penelitian ini adalah Specimen \#1, \#2 dan \#3 dari penelitian Kaplan (1954). Jari-jari kelengkungan cangkang, $\mathrm{R}=20$ inches. Bahan spesimen dibuat dari logam paduan aluminiummagnesium QQ-M-44 dengan data propertis $\mathrm{E}=6,5 \times 10^{6}$ psi dan $v=0,32$. Data lainnya disajikan pada Tabel 1 .

Tabel 1. Data geometri cangkang bola

\begin{tabular}{ccccc}
\hline No. & Kode & $\begin{array}{c}\text { Tebal, t } \\
\text { (in.) }\end{array}$ & $\begin{array}{c}\text { Tinggi, h0 } \\
\text { (in.) }\end{array}$ & $\boldsymbol{\lambda}$ \\
\hline 1 & Spec \# 1 & 0.101 & 0.251 & 4.04 \\
2 & Spec \# 2 & 0.099 & 0.253 & 4.08 \\
3 & Spec \# 3 & 0.101 & 0.256 & 4.16 \\
\hline \multicolumn{5}{l}{ Sumber: Kaplan(1954). }
\end{tabular}

Berikut ini dijelaskan variabel yang digunakan dalam penelitian ini:

a. Parameter geometri cangkang $\lambda$

Hubungan antar variabel geometri dinyatakan dengan parameter geometri cangkang $\lambda$ (Kaplan, 1954; Uchiyama dan Yamada, 2000), yaitu:

$\lambda=\left[12\left(1-v^{2}\right)\right]^{1 / 4} \frac{\mathrm{a}}{\sqrt{\mathrm{Rt}}}$

Sedangkan hubungan antara tinggi cangkang $\mathrm{h}_{0}$ dengan radius kelengkungan $\mathrm{R}$ dan radius dasar cangkang dapat diambil dari persamaan bola $\mathrm{a}=\sqrt{ }\left[\mathrm{h}_{0}\left(2 \mathrm{R}-\mathrm{h}_{0}\right)\right]$.

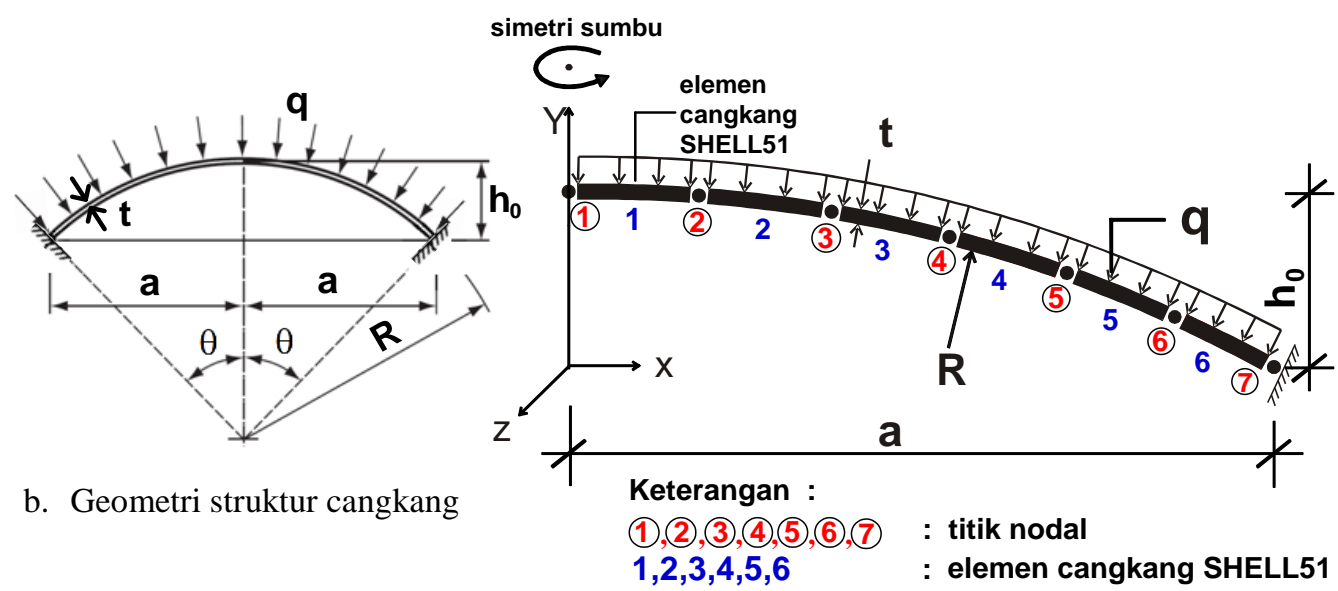

a. Model elemen hingga cangkang simetri sumbu

Gambar 1. Geometri dan model elemen hingga struktur cangkang simetri sumbu SHELL51 dibebani tekanan merata q bertumpuan jepit. 
b. Beban tekanan cangkang nondimensional, $\mathrm{q} / \mathrm{q}_{0}$

Agar beban tekanan dapat dinyatakan nondimensional maka diambil suatu nilai pembanding yaitu beban tekanan kritis dari teori linier klasik. Solusi teori linier klasik beban kritis buckling cangkang bola (spherical shell) mulamula ditemukan oleh Zolley dalam disertasinya pada tahun 1915. Berdasarkan teori elastis linier, dengan asumsi deformasi kecil dan elastis, beban kritis cangkang bola $\mathrm{q}_{0}$ yang dibebani tekanan merata bertumpuan jepit adalah (Timoshenko dan Gere, 1961):

$q_{0}=\frac{2 E}{\sqrt{3\left(1-v^{2}\right)}}\left(\frac{t}{R}\right)^{2}$

c. Perpindahan pada apex, Uoy

Besarnya perpindahan atau perpindahan arah vertikal setiap titik pada permukaan cangkang dinyatakan dengan notasi Uy, sedangkan perpindahan pada puncak cangkang atau apex dinyatakan dengan Uoy. Notasi perpindahan apex nondimensional digunakan perbandingan tingi cangkang $\mathrm{h}_{0}$ yaitu Uoy $/ \mathrm{h}_{0}$. Untuk nilai Uoy $/ \mathrm{h}_{0}=1$ berarti titik cangkang berada pada posisi mendatar yaitu titik apex dan titik tumpuan berada pada posisi dalam satu garis horizontal.

\section{Pemodelan elemen hingga cangkang}

Struktur cangkang bola (spherical shell) dibebani tekanan merata dengan tumpuan jepit di tepi dimodelkan dengan 6 elemen dan 7 titik nodal seperti pada Gambar 1.b. Jenis elemen cangkang yang digunakan dalam penelitian ini adalah elemen cangkang simetri sumbu (axisymmetric shell) dan elemen cangkang segiempat dengan 4 titik nodal per elemen. Pada penelitian ini digunakan Program ANSYS dengan jenis elemen SHELL51 (axisymmetric structural shell).

Pengaruh penguatan tegangan digunakan untuk memperhitungkan pengaruh gaya membran pada cangkang yang dapat menyebabkan buckling. Elemen SHELL51 memiliki dua titik nodal dimana terdapat empat derajat kebebasan pada setiap titik nodal, yaitu: translasi titik nodal pada arah $\mathrm{X}$, arah $\mathrm{Y}$, dan arah $\mathrm{Z}$ serta rotasi terhadap sumbu $\mathrm{Z}$ dinotasikan Ux, Uy, Uz dan $\theta z$ (atau $\mathrm{ROT}_{\mathrm{z}}$ ), sebagaimana ditunjukkan pada Gambar 2. Pemodelan elemen cangkang simetri sumbu SHELL51 divalidasi dengan jenis elemen cangkang segiempat nonlinier elastis 4 titik nodal SHELL63 pada Program ANSYS 12.0 (ANSYS, 2009).

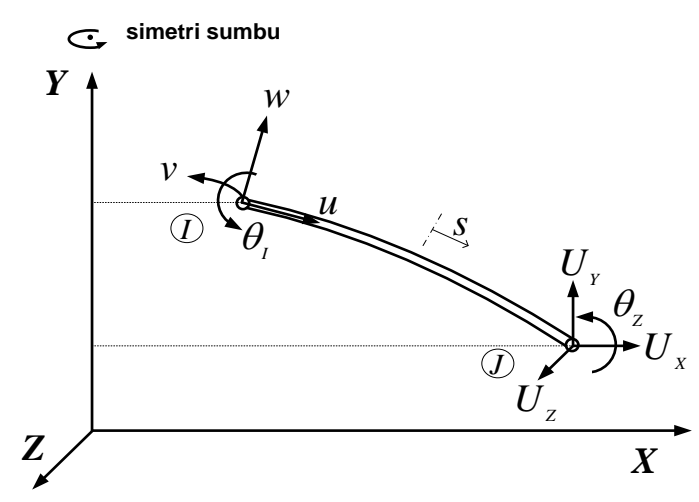

\section{Gambar 2. Notasi derajat kebebasan titik nodal untuk elemen cangkang simetri sumbu.}

\section{Analisis non linier geometri}

Pada analisis nonlinier, persamaan kesetimbangan dilakukan pada konfigurasi akhir dan solusi yang digunakan untuk mendapatkan hubungan bebanperpindahan adalah formulasi inkremental dari teori Lagrangian. Matriks kekakuan elemen dan vektor beban diturunkan menggunakan sebuah formulasi updated Lagrangian. Prosedur selengkapnya telah diturunkan oleh Bathe (1982) dan ANSYS (2009).

Persamaan kesetimbangan struktur pada tahap ke-n dan iterasi ke-i adalah:

$[\mathrm{K}]\left\{\Delta \mathrm{u}_{\mathrm{i}}\right\}=\left\{\mathrm{F}^{\mathrm{a}}\right\}-\left\{\mathrm{F}_{\mathrm{i}}^{\mathrm{nr}}\right\}$

dimana $[\mathrm{K}]$ adalah matriks kekakuan singgung atau tangen dalam bentuk:

$[\mathrm{K}]=\left[\mathrm{Ko}_{\mathrm{i}}\right]+\left[\mathrm{K} \sigma_{i}\right]$

dimana [Ko] adalah matriks kekakuan pada umumnya, yaitu:

$\left[K_{o_{i}}\right]=\int\left[B_{i}\right]^{\top}\left[D_{i}\right]\left[B_{i}\right] d($ vol $)$

dimana $\left[\mathrm{B}_{\mathrm{i}}\right]^{\mathrm{T}}$ adalah matriks relasi reganganperpindahan pada geometri $\left\{\mathrm{X}_{\mathrm{n}}\right\}$ dan $\left[\mathrm{D}_{\mathrm{i}}\right]$ matriks relasi tegangan-regangan. Sedangkan $\left[\mathrm{K}_{\mathrm{\sigma i}}\right]$ adalah kontribusi tegangan atau matriks kekakuan geometri ditulis dalam bentuk simbol:

$\left[K_{\sigma_{i}}\right]=\int\left[G_{i}\right]^{\top}\left[\tau_{i}\right]\left[G_{i}\right] d($ vol $)$

dimana $\left[\mathrm{G}_{\mathrm{i}}\right]^{\mathrm{T}}$ adalah matriks turunan fungsi bentuk (shape function) dan $\left[\tau_{\mathrm{i}}\right]$ adalah matriks Cauchy untuk tegangan $\left\{\sigma_{\mathrm{i}}\right\}$ pada sistem koordinat global. $\left\{\mathrm{F}^{\mathrm{a}}\right\}$ adalah gaya yang dikerjakan pada tahapan iterasi ke-i, $\left\{\mathrm{F}_{\mathrm{i}}^{\mathrm{nr}}\right\}$ dalam Persamaan (3) adalah gaya residu Newton-Raphson yaitu:

$\left[F_{i}^{n r}\right]=\int\left[B_{i}\right]^{\top}\left[\sigma_{i}\right] d($ vol $)$ 
Simbol n menyatakan inkremental beban tahap ken sedangkan i menyatakan iterasi ke-i.

Formulasi elemen hingga pada cangkang simetri sumbu dapat dijumpai pada Cook (1995).

Perpindahan titik nodal pada elemen simetri sumbu diuraikan dalam dua komponen yaitu $\mathrm{v}$ dan w dalam arah meridian dan melingkar (hoop). Hubungan antara regangan - perpindahan dinyatakan dengan: matriks kekakuan elemen secara umum dapat dinyatakan dengan:

$$
[K]_{e}=\int_{A}[B]^{\top}[D][B] d A
$$

Pada elemen simetri sumbu, luas elemen dapat dinyatakan dengan $d \mathrm{~A}=2 \pi r d s=2 \pi r L d s_{1}$ Dengan demikian matriks kekakuan elemen cangkang simetri sumbu:

$$
[K]_{\mathrm{e}}=2 \pi \mathrm{L} \int_{0}^{1}[B]^{\top}[D][B] r d s_{1}
$$

\section{Teknik solusi metode Newton-Raphson}

Metode Iterasi merupakan metode yang sering digunakan untuk menyelesaikan persamaan kesetimbangan non linier, disamping metode Inkremental. Metode Iterasi yang digunakan adalah metode Newton-Raphson dengan solusi linier pada pendekatan pertama. Untuk Iterasi selanjutnya, regangan dan tegangan yang sesungguhnya ditentukan dengan menghitung baik linier maupun kontribusi non linier dari pendekatan sebelumnya. Metode NewtonRaphson memiliki keunggulan kecepatan konvergen, namun demikian metode NewtonRaphson dengan kontrol beban tidak dapat melacak pada daerah ekstrim dekat beban batas. Untuk mendapatkan solusi konvergen dan ketepatan hasil pada daerah ekstrim di daerah beban batas digunakan metode panjang busur konstan (constant arc-length).

Proses diskritisasi elemen hingga memberikan sejumlah persamaan simultan:

$[\mathrm{K}]\{\mathrm{u}\}=\left\{\mathrm{F}^{\mathrm{a}}\right\}$

dimana $[\mathrm{K}]$ adalah matriks kekakuan fungsi perpindahan $\{\mathrm{u}\}$ adalah vektor nilai DOF (degree of freedom) perpindahan yang tidak diketahui, dan $\left\{\mathrm{F}^{\mathrm{a}}\right\}$ adalah vektor beban yang bekerja. Karena koefisien matriks $[\mathrm{K}]$ adalah fungsi dari perpindahan $\{u\}$ atau turunannya, maka Persamaan (10) tersebut adalah persamaan nonlinier.

Metode Newton-Raphson dapat digunakan untuk menyelesaikan persamaan nonlinier dengan inkremental beban dan proses iterasi dengan persamaan sebagai berikut (ANSYS,2004; Bathe,1982):

$\left[\mathrm{K}_{\mathrm{i}}^{\top}\right]\left\{\Delta \mathrm{u}_{\mathrm{i}}\right\}=\left\{\mathrm{F}^{\mathrm{a}}\right\}-\left\{\mathrm{F}_{\mathrm{i}}^{\mathrm{nr}}\right\}$
$\left\{\mathrm{u}_{\mathrm{i}+1}\right\}=\left\{\mathrm{u}_{\mathrm{i}}\right\}+\left\{\Delta \mathrm{u}_{\mathrm{i}}\right\} \ldots$

dimana $\left[\mathrm{K}_{\mathrm{i}}^{\mathrm{T}}\right]$ matriks kekakuan tangent, $\mathrm{i}$ dan $\mathrm{n}$ adalah subskrip yang menunjukkan urutan iterasi ke-i, dan step atau tahapan beban ke-n dan $\left\{\mathrm{F}_{\mathrm{i}}^{\mathrm{nr}}\right\}$ adalah vektor beban pemulihan (restoring loads) sesuai dengan gaya atau tegangan elemen $\left[\mathrm{K}_{\mathrm{i}}^{\mathrm{T}}\right]$ dan $\left\{\mathrm{F}_{\mathrm{i}}^{\mathrm{nr}}\right\}$ dievaluasi berdasarkan nilai perpindahan $\left\{\mathrm{u}_{\mathrm{i}}\right\}$ yang diberikan. Ruas kanan Persamaan (11) adalah residu atau vektor beban out-of-balance. Solusi tahapan beban pada Newton-Raphson dengan langkah iterasi pada setiap tambahan beban diilustrasikan pada Gambar 3 (ANSYS, 2009).

Solusi yang diperoleh pada akhir proses iterasi adalah beban pada suatu tahap $\left\{\mathrm{F}^{\mathrm{a}}\right\}$. Solusi konvergensi akhir akan berada dalam kesetimbangan sampai vektor beban restore $\left\{\mathrm{F}_{\mathrm{i}}^{\mathrm{nr}}\right\}$ (dihitung dari tegangan yang terjadi) sama atau mendekati dengan vektor beban yang bekerja $\left\{\mathrm{F}^{\mathrm{a}}\right\}$. Prosedur inkremental NewtonRaphson akan konvergen jika dan hanya jika solusi pada setiap iterasi $\left\{\mathrm{u}_{\mathrm{i}}\right\}$ mendekati solusi eksaknya.

Teknik analisis nonlinier selain memerlukan proses penyelesaian pada setiap langkah dengan cara iterasi, juga dilakukan beban bertahap dengan analisis inkremental. Vektor beban akhir yang bekerja $\left\{\mathrm{F}^{\mathrm{a}}\right\}$ dibagi secara bertahap dan tiap tahap dilakukan iterasi Newton-Raphson pada setiap langkah.

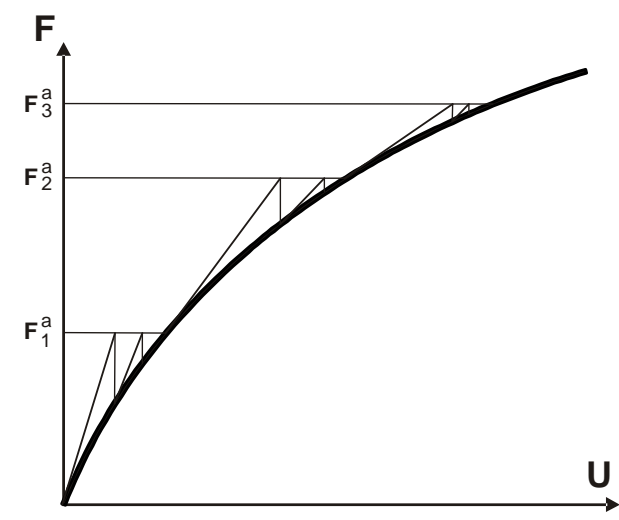

Gambar 3. Prosedur inkremental beban pada metode Newton-Raphson (ANSYS, 2004)

\section{Metode panjang busur (arc-length)}

Metode panjang busur konstan dikembangkan oleh Crisfield dari metode sebelumnya oleh 
Wempner dan Risk (Crisfield,1980). Metode panjang busur dapat mengatasi masalah respon struktur setelah titik kritis post-buckling seperti perilaku instabilitas snap-through pada struktur cangkang.

Metode panjang busur konstan menggunakan iterasi bulatan atau busur lingkaran untuk mempertahankan ortogonalitas antara radius panjang busur dengan arah ortogonal. Hal ini berangkat dari asumsi bahwa semua besaran beban dapat dikontrol dengan sebuah parameter skalar sebagai faktor beban. Secara matematis, metode panjang busur merupakan melacak trase kurva kesetimbangan yang direntang oleh variabel perpindahan titik nodal dan faktor beban. Oleh karena itu, metode NewtonRaphson masih menjadi metode dasar untuk solusi panjang busur. Ilustrasi teknik solusi metode panjang busur seperti tampak pada Gambar 4.

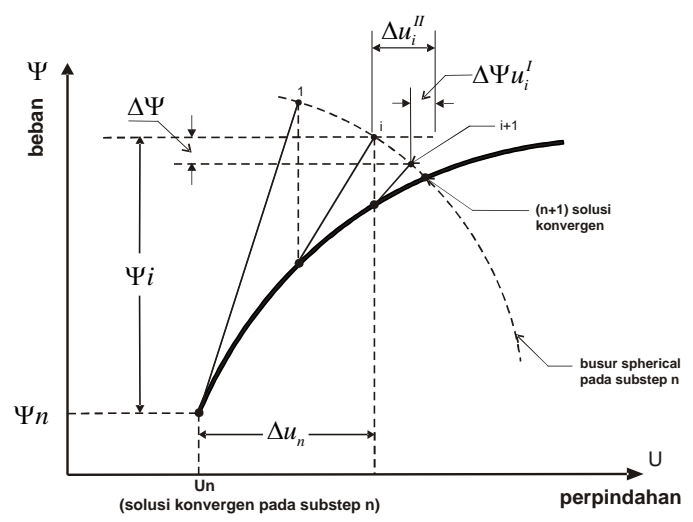

\section{Gambar 4. Teknik solusi metode panjang busur (arc-length).}

Persamaan nonlinier pada prosedur panjang busur dapat ditulis sebagai berikut (Crisfield,1980 dan ANSYS, 2009):

$\left[\mathrm{K}_{\mathrm{i}}^{\top}\right]\left\{\Delta \mathrm{u}_{\mathrm{i}}\right\}=\psi\left\{\mathrm{F}^{\mathrm{a}}\right\}-\left\{\mathrm{F}_{\mathrm{i}}^{\mathrm{nr}}\right\}$.

dimana $\Psi$ adalah parameter tingkat beban, pada umumnya nilai $\Psi$ berkisar $-1 \leq \Psi \leq 1$. Bentuk persamaan nonlinier pada substep ke-n, iterasi ke-i dengan memasukkan parameter tingkat beban adalah :

$\left[\mathrm{K}_{\mathrm{i}}^{\top}\right]\left\{\Delta \mathrm{u}_{\mathrm{i}}\right\}-\Delta \psi\left\{\mathrm{F}^{\mathrm{a}}\right\}=\left(\Psi_{n}+\Psi_{i}\right)\left\{\mathrm{F}^{\mathrm{a}}\right\}-\left\{\mathrm{F}_{\mathrm{i}}^{\mathrm{nr}}\right\}=-\left\{\mathrm{R}_{\mathrm{i}}\right\} \cdots \cdots$

dimana $\Delta \Psi$ adalah inkremental parameter tingkat beban.

Inkremental perpindahan $\left\{\Delta \mathrm{U}_{\mathrm{i}}\right\}$ dapat ditulis dalam dua bagian yaitu:

$$
\left\{\Delta u_{i}\right\}=\Delta \psi\left\{\Delta u_{i}^{\prime}\right\}+\left\{\Delta u_{i}^{\prime \prime}\right\}
$$

dimana $\left\{\Delta \mathrm{u}_{\mathrm{i}} \mid\right\}$ adalah perpindahan akibat satuan tingkat beban, $\left\{\Delta \mathrm{u}_{\mathrm{i}}{ }^{\|}\right\}$adalah inkremental perpindahan metode Newton-Raphson, dimana:

$\left\{\Delta \mathrm{u}_{\mathrm{i}}^{\prime \prime}\right\}=\left[\mathrm{K}_{\mathrm{i}}^{\mathrm{T}}\right]^{-1}\left\{\mathrm{~F}^{\mathrm{a}}\right\}$

$\left\{\Delta u_{i}^{\prime \prime}\right\}=-\left[K_{i}^{T}\right]^{-1}\left\{R_{i}\right\}$

Pada setiap iterasi panjang busur menggunakan Persamaan (14) dan (15) untuk mendapatkan $\left\{\Delta \mathrm{u}_{\mathrm{i}}\right\}$ dan $\left\{\Delta \mathrm{u}_{\mathrm{i}}{ }^{\|}\right\}$.

Inkremental tingkat beban $\Delta \Psi$ pada Persamaan (15) dihitung dengan persamaan panjang busur untuk iterasi ke-i sebagai berikut:

$\ell_{i}^{2}=\psi_{i}^{2}+\beta^{2}\left\{\Delta u_{n}\right\}\left\{\Delta u_{n}\right\}^{\top}\left\{\Delta u_{n}\right\}$

dimana $\beta$ faktor skala (dalam unit perpindahan), dan $\ell_{i}$ adalah radius panjang busur (dalam skala gaya).

Persamaan (15) dan (17) digunakan untuk menghitung solusi vector $\left(\Delta \mathrm{u}_{\mathrm{i}}, \Delta \Psi\right)^{\mathrm{T}}$. Inkremental tingkat beban $\Delta \Psi$ dapat dihitung dengan:

$\Delta \psi=\frac{r_{i}-\left\{\Delta u_{n}\right\}^{\top}\left\{\Delta u_{i}^{\prime \prime}\right\}}{\beta^{2} \Psi_{i}+\left\{\Delta u_{n}\right\}^{\top}\left\{\Delta u_{i}^{\prime \prime}\right\}}$

dimana $r_{i}$ adalah residual skalar untuk iterasi eksplisit pada hitungan busur pertama.

Konvergensi diperoleh ketika ukuran beban residu atau sisa dan/atau kenaikan perpindahan kurang dari toleransi kali nilai referensi. Nilai toleransi dalam studi ini diambil nilai default sebesar $\varepsilon_{\mathrm{R}}=0,001$ untuk gaya dan untuk perpindahan $\varepsilon_{\mathrm{U}}=0,01$.

\section{Hasil dan Pembahasan}

Model cangkang simetri sumbu jenis elemen SHELL51 dilakukan uji perbandingan antara hasil penelitian ini dengan data hasil eksperimen Kaplan (1954). Hasil ekperimen ini banyak dirujuk oleh peneliti berikutnya antara lain: Uchiyama dan Yamada (2000). Benda uji atau spesimen berupa cangkang bola dangkal bertumpuan jepit dengan beban tekanan merata.

Tiga buah spesimen pertama yaitu Spec\#1, Spec\#2, Spec\#3 dari eksperimen Kaplan (1954) dilakukan studi perbandingan karena tersedia data baik eksperimen maupun hasil analisis numerik beda hingga (dalam bentuk kurva dan persamaan polinomial). Kurva beban-lendutan hasil eksperimen dan analisis penelitian Kaplan (1954). Hasil analisis nonlinier elemen hingga studi ini untuk model elemen cangkang simetri sumbu 
SHELL51 dan elemen cangkang 3 dimensi SHELL63 disajikan pada Gambar 5, Gambar 6 dan Gambar 7.

Hasil ketiga benda uji tersebut menunjukkan terjadi snap-through buckling. Perilaku snapthrough buckling ditunjukkan dengan adanya titik kritis maksimum dan titik kritis minimum.

Dalam Gambar 5 ditunjukkan kurva bebanperpindahan hasil perbandingan antara model cangkang simetri sumbu jenis elemen SHELL51 dengan model cangkang 3 dimensi jenis elemen SHELL63. Tidak terdapat perbedaan signifikan hasil antara penggunaan jenis elemen dan pembagian elemen yang dipilih antara jenis elemen simetri sumbu SHELL51 dengan jenis elemen cangkang 3 dimensi SHELL63. Hasil ini menunjukkan penggunaan jenis elemen simetri sumbu SHELL51 lebih efisien karena dengan jumlah elemen jauh lebih sedikit (6 berbanding $48 \times 6)$.

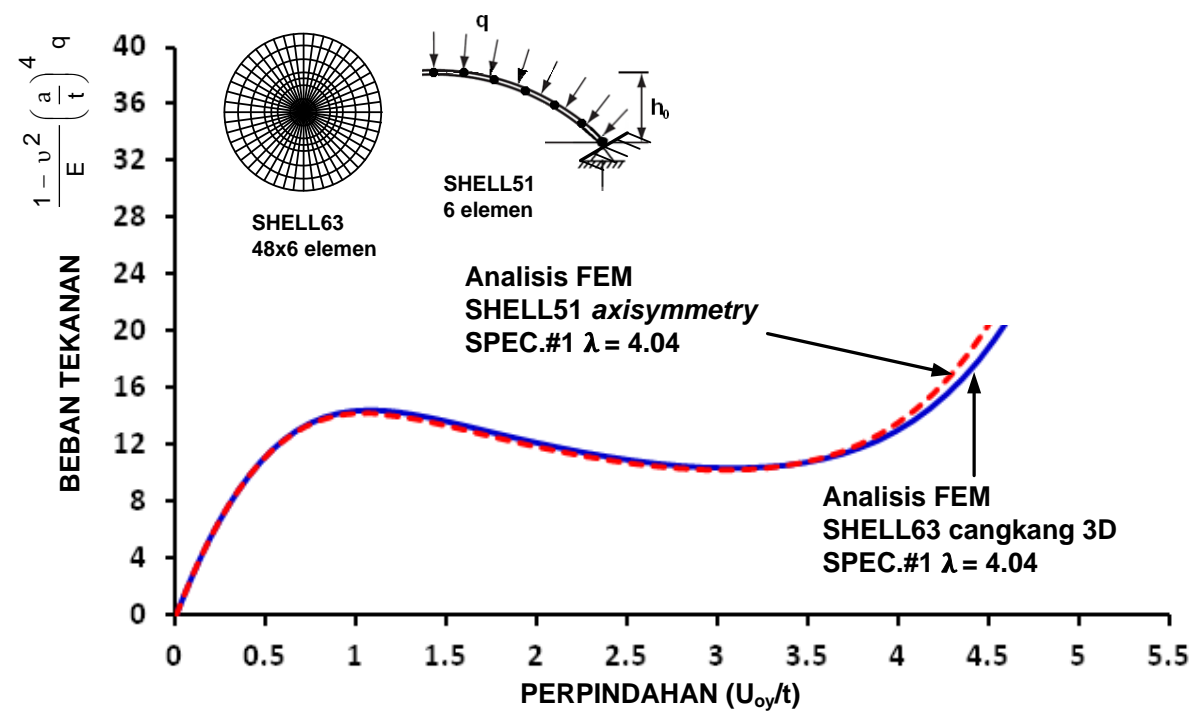

Gambar 5. Perbandingan kurva beban-perpindahan spesimen SPEC.\#1 $\lambda=4,04$.

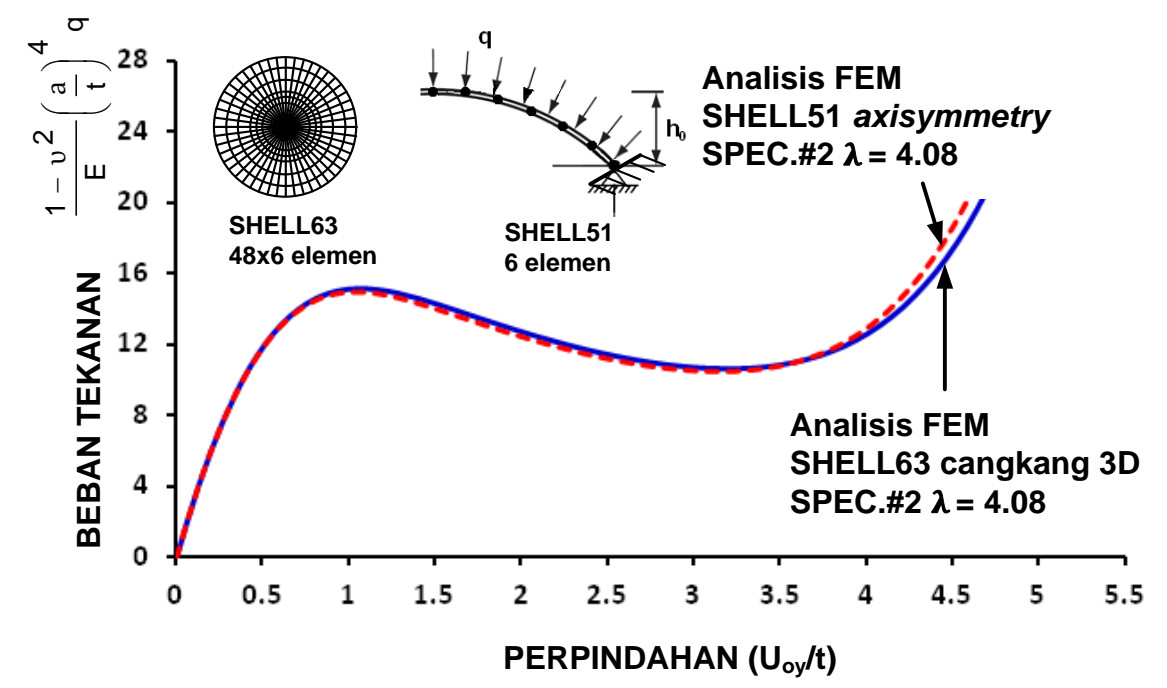

Gambar 6. Perbandingan kurva beban-perpindahan spesimen SPEC.\#2, $\lambda=4,08$. 


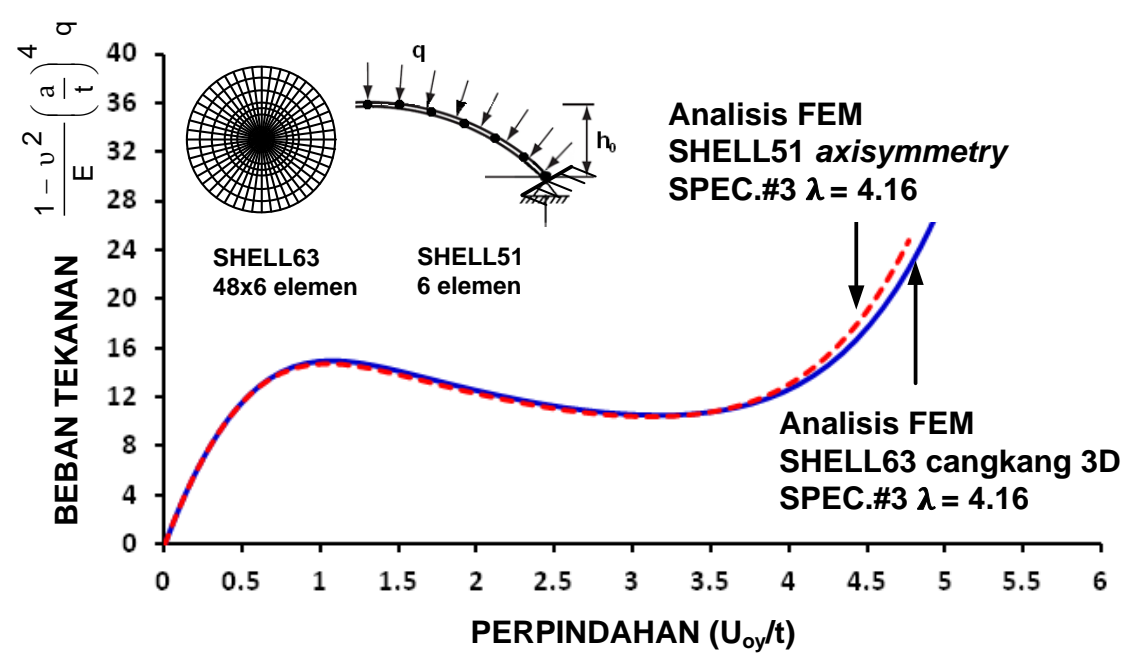

Gambar 7. Perbandingan kurva beban-perpindahan spesimen SPEC.\#3 $\lambda=4,16$.

Gambar 8, Gambar 9 dan Gambar 10 menunjukkan kurva beban-perpindahan perbandingan antara hasil eksperimen dan hasil analisis Kaplan (1954) dengan hasil analisis elemen hingga studi ini. Hasil analisis elemen hingga studi ini lebih mendekati hasil analisis Kaplan, namun lebih tinggi dibandingkan dengan hasil eksperimen. Pada Tabel 2 ditunjukkan perbandingan beban tekanan kritis hasil eksperimen dengan hasil analisis nonlinier FEM sebesar 0,86; 0,78 dan 0,82. Hasil analisis nonlinier FEM ini mendekati hasil analisis Kaplan dengan perbandingan yang hampir sama yaitu 0,$84 ; 0,84$ dan 0,85 .

Perbedaan antara hasil eksperimen dengan hasil analisis oleh studi Kaplan (1954) sendiri maupun hasil analisis elemen hingga studi ini disebabkan karena faktor ketidak sempurnaan (imperfection) dalam eksperimen cangkang bola yang sulit untuk dihindari. Hal ini sesuai dengan pernyataan dari
Kaplan bahwa meskipun sudah diusahakan dengan baik, namun set-up spesimen belum sebaik yang diharapkan (unfortunately it is still not so good as would be desired).

Tabel 2. Perbandingan analisis dengan hasil eksperimental

\begin{tabular}{ccccc}
\hline No. & Kode & $\boldsymbol{\lambda}$ & $\begin{array}{c}\text { qcr.exp. } \\
/ \mathbf{q}_{\text {cr.NL }}\end{array}$ & $\begin{array}{c}\text { qcr.exp. } \\
/ \mathbf{q} \text { cr.NL.K }\end{array}$ \\
\hline 1 & Spec \# 1 & 4,04 & 0,86 & 0,84 \\
2 & Spec \# 2 & 4,08 & 0,78 & 0,84 \\
3 & Spec \# 3 & 4,16 & 0,82 & 0,85 \\
\hline
\end{tabular}

dimana:

$\mathrm{q}_{\text {cr.exp. }}=$ beban kritis eksperimental Kaplan(1954).

$\mathrm{q}_{\mathrm{cr} . \mathrm{AK}}=$ beban kritis analisis Kaplan(1954).

$\mathrm{q}_{\mathrm{cr} . \mathrm{NL}}=$ beban kritis analisis nonlinier studi ini.

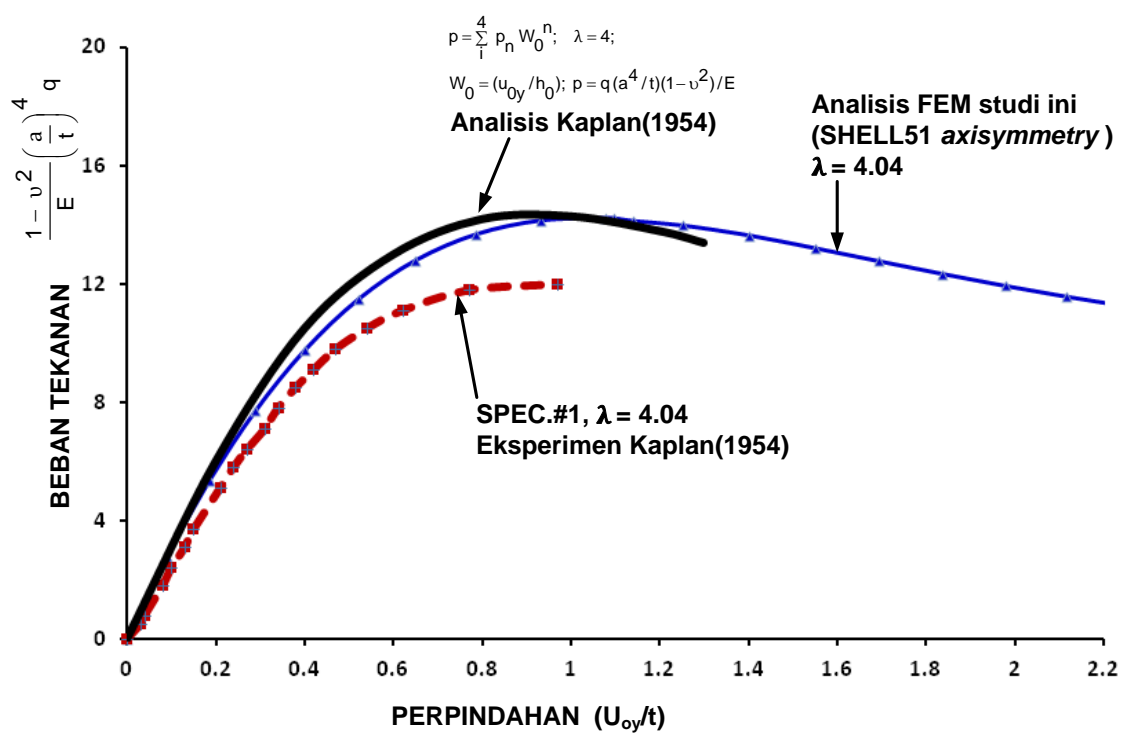

Gambar 8. Perbandingan kurva beban-perpindahan hasil Finite Element Method (FEM) dengan hasil penelitian Kaplan (1954) Spec\#1. 


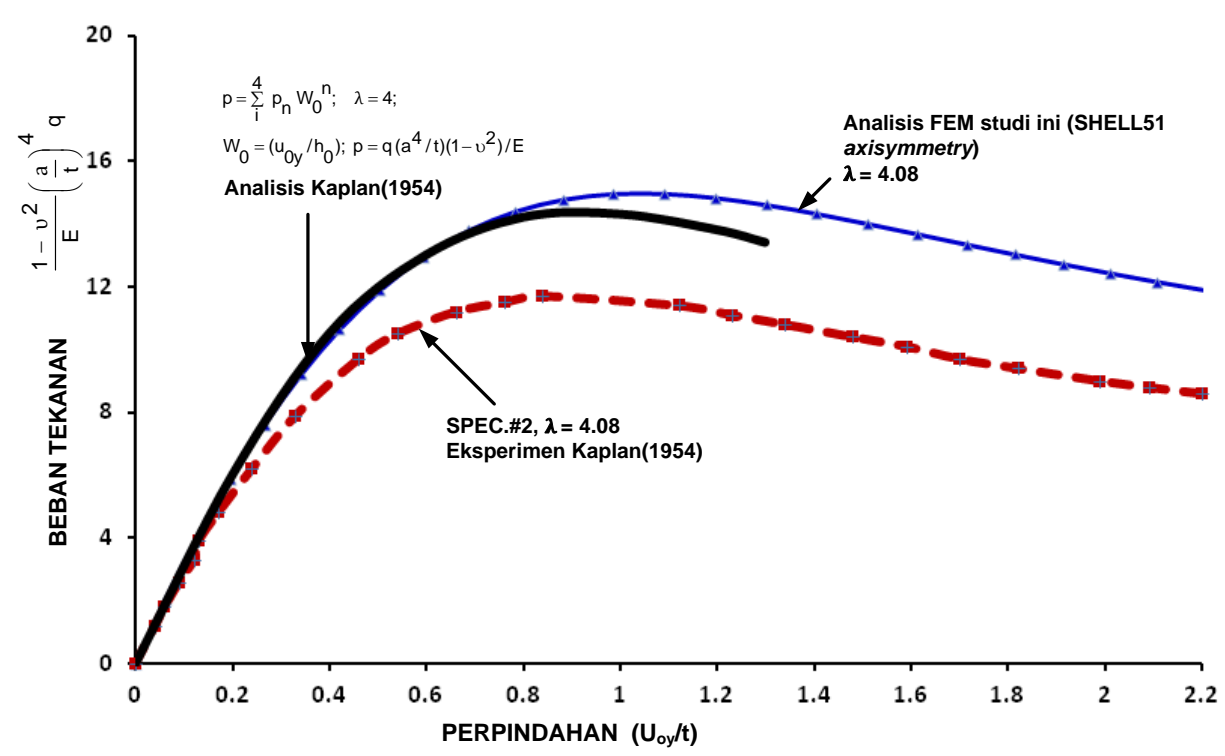

Gambar 9. Perbandingan kurva beban-perpindahan hasil Finite Element Method (FEM) dengan hasil penelitian Kaplan (1954) Spec\#2; $\lambda=4,08 ; t=0,099$ in.; $h 0=0,253$ in.

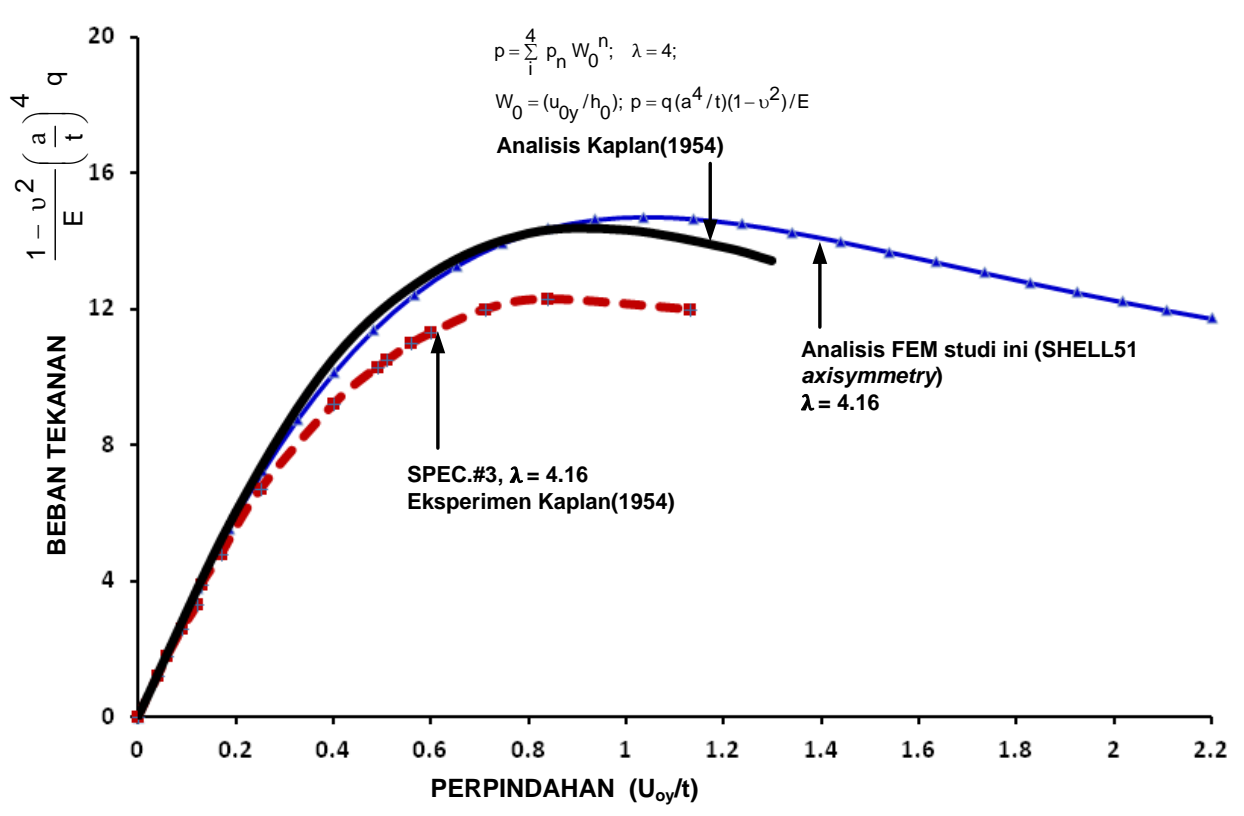

Gambar 10. Perbandingan kurva beban-perpindahan hasil Finite Element Method (FEM) dengan hasil penelitian Kaplan (1954) Spec\#3; $\lambda=4,16 ; t=0,101$ in.; $h 0=0,256$ in.

\section{Kesimpulan}

Dari hasil dan pembahaan di atas dapat disimpulkan:

a. Struktur cangkang bola bertumpuan jepit dibebani tekanan merata dengan parameter geometri $\quad \lambda=4,04 ; \quad \lambda=4,08 ; \quad$ dan $\quad \lambda=4,16$ berperilaku nonlinier snap-through buckling ditunjukkan dengan adanya beban kritis maksimum dan minimum pada kurva bebanperpindahan. b. Kurva beban-perpindahan hasil analisis elemen hingga nonlinier dengan jenis elemen simetri sumbu SHELL51 (6 elemen) dan elemen segiempat SHELL63 (48x6) tidak menunjukkan perbedaan yang signifikan. Oleh karena itu penggunakan elemen cangkang simetri sumbu pada kasus struktur simetri dengan beban simetri jauh lebih efisien.

c. Perbandingan beban tekanan kritis hasil eksperimen dari Kaplan (1954) dengan hasil analisis elemen hingga penelitian ini menunjukkan hasil yang lebih rendah dengan 
perbandingan antara $0,78 \mathrm{~s} / \mathrm{d} \quad 0,86$. Hal ini disebabkan karena pada ekperimen terdapat ketidaksempurnaan geometri yang sangat sentitif terhadap perilaku struktur.

d. Teknik arc-length pada analisis nonlinier geometri dapat menemukan titik-titik kesetimbangan post-buckling dengan kurva beban-perpindahan turun atau kekakuan sistem struktur negatif. Pada struktur cangkang dengan parameter geometri $\lambda=4,04 ; \lambda=4,08$; dan $\lambda=4,16$ konvergensi cepat dapat ditemukan dengan jumlah langkah beban (load step) sebesar $\mathrm{N}=25$.

\section{Ucapan Terima Kasih}

Penelitian ini merupakan bagian dari penelitian disertasi pada Program Doktor Teknik Sipil Universitas Dinonegoro Semarang, Indonesia. Ucapakan terimakasih kepada Kepala Laboratorium Perancangan dan Tribologi dan dosen Jurusan Teknik Mesin Universitas Diponegoro Semarang atas ijin dan bantuannya dalam penelitian ini menggunakan fasilitas simulasi komputasi numerik Finite Element Method (FEM) dengan Program ANSYS.

\section{Daftar Pustaka}

ANSYS, 2009. Theory Reference for the Mechanical APDL and Mechanical Applications, Release 12.1, ANSYS, Inc. Southpointe 275 Technology Drive, Canonsburg.
Bathe, K.J., 1982. Finite Element Procedures in Engineering Analysis, Prentice-Hall, New Jersey.

Cook, R.D., 1995. Finite Element Modeling for Stress Anslysis, John Wiley \& Sons, Inc., Canada.

Crisfield, M.A., 1980. A Fast Incremental/ Iterative Solution Procedure that Handles "SnapThrough”, Computer and Structures Vol.13 pp.5562, England.

Eurocode-3., 2007. Design of Steel Structures, Part 1-6: Strength and Stability of Shell Structures, European Committee for Standardization, Management Centre: rue de Stassart, 36 B-1050 Brussels.

Kaplan, A., 1954. Finite Deflection and Bending of Curved and Shallow Spherical Shells under Lateral Loads, Thesis Doctor of Philosophy, California Institute of Technology Pasadena, California.

Lagace, P.A., 2002. Stability and Buckling. Unit V, MIT, Opencourse Fall 2002, USA.

Timoshenko, S. P., dan Gere, J.M., 1961. Theory of Elastic Stability, McGraw-Hill Book Company, Inc. New York.

Uchiyama, M. dan Yamada, S., 2000. Nonlinier Buckling Simulations of Imperfect Shell Domes using a Hybrid Finite Element Formulation and the Agreement with Experiments, Fourth International Colloquium on Computation of Shell \& Spatial Structures, Chania-Crete, Greece. 